\title{
Effect of alkaline lignin modification on cellulase-lignin interactions and enzymatic saccharification yield
}

\author{
Wenjun Ying ${ }^{1,2}$, Zhengjun Shi ${ }^{1,2}$, Haiyan Yang ${ }^{1,2}$, Gaofeng $X u^{2}$, Zhifeng Zheng ${ }^{1}$ and Jing Yang ${ }^{1,2^{*}}$ (D)
}

\begin{abstract}
Background: The lignin can compete for binding cellulase enzymes with cellulose fibers and decrease the accessibility of enzymes to carbohydrates. The competitive adsorption of cellulase to lignin mainly depended on the chemical structure of lignin. The post-pretreatment can decrease the lignin content and modify the lignin structure of pretreated substrates, which reduced the lignin inhibition on enzymatic saccharification. Therefore, the post-treatment by modifying the lignin structure would attract considerable attention for weakening the cellulase-lignin interactions.

Results: Three modified lignins, including sulfonated lignin (SL), oxidized lignin (OL), and carboxylated lignin (CL), were prepared from alkali lignin (AL) and their structures and physicochemical properties were characterized using FTIR, NMR, XPS analysis, zeta potential, and contact angle, respectively. Compared to AL, three modified lignin preparations exhibited the decrease in contact angle by $61-70 \%$ and phenolic hydroxyls content by $17-80 \%$, and an obvious increase of negative charges by about $21-45 \%$. This was mainly due to the drop of condensation degree and the incorporation of carboxylic and sulfonic acid groups into modified lignins. Langmuir adsorption isotherms showed that the affinity strength between cellulase and modified lignins significantly reduced by $54-80 \%$. Therefore, the $72 \mathrm{~h}$ hydrolysis yield of Avicel with SL, OL, and CL was 48.5, 51.3, and 49.4\%, respectively, which was increased 8-15.3\% than that of Avicel with $\mathrm{AL}, 44.5 \%$. In the enzymatic hydrolysis of bamboo biomass, the glucose yield at $5 \mathrm{~d}$ was $38.5 \%$ for AS-P. amarus, 15.4\% for AO-P. amarus and 21.4\% for AC-P. amarus, respectively, which were 1.4-3.5 times of alkali pretreated P. amarus.
\end{abstract}

Conclusions: The post-treatment can weaken the nonproductive adsorption between lignin and cellulase proteins and improve the enzymatic saccharification efficiency. This study will provide a conceptual combination of pretreatment technologies and post-pretreatment by modifying lignin structure for reducing the cellulase-lignin interaction.

Keywords: Lignocellulosic biomass, Biomass pretreatment, Lignin modification, Nonproductive adsorption, Enzymatic saccharification

\section{Background}

Biochemical conversion of lignocellulosic biomass to sugar-based compounds has been devoted for the production of biofuels and platform chemicals such as 5-hydroxymethylfurfural and furfural [1]. A crucial commercialization-limiting step in the processes is the

\footnotetext{
*Correspondence: kmjingyang@163.com

${ }^{1}$ Key Laboratory for Forest Resources Conservation and Utilization in the Southwest Mountains of China, Ministry of Education, Southwest Forestry University, Kunming 650224, China

Full list of author information is available at the end of the article
}

enzymatic hydrolysis of polysaccharides in lignocellulose to simple sugars [2]. The factors affecting enzymatic hydrolysis of lignocellulosic biomass includes substrate-related factors, mainly consisting of the presence of lignin and hemicellulose in biomass, the degree of polymerization and crystallinity of cellulose, the surface area accessible to cellulases, and enzyme-related factors $[3,4]$. Amongst factors, lignin plays an inhibitory role in the enzymatic digestibility of polysaccharides in plant cell walls.

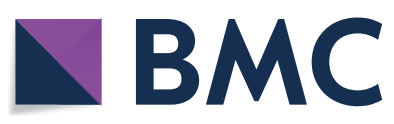

C The Author(s) 2018. This article is distributed under the terms of the Creative Commons Attribution 4.0 International License (http://creativecommons.org/licenses/by/4.0/), which permits unrestricted use, distribution, and reproduction in any medium, provided you give appropriate credit to the original author(s) and the source, provide a link to the Creative Commons license, and indicate if changes were made. The Creative Commons Public Domain Dedication waiver (http://creativecommons.org/ publicdomain/zero/1.0/) applies to the data made available in this article, unless otherwise stated. 
Lignin is a cross-linked polymer and consists of different phenylpropane, such as $p$-hydroxyphenyl $(\mathrm{H})$, guaiacyl (G), and syringyl (S) units, through the linkage of various interunit linkages, such as $\beta-O-4^{\prime}, \beta-5^{\prime}, \beta-\beta^{\prime}$, $5-5^{\prime}, 5-O-4^{\prime}$, and $\beta-1^{\prime}[5,6]$. In addition, lignin contains plentiful functional groups, such as aliphatic hydroxyl, phenolic hydroxyl, carbonyl, carboxyl, and methyl groups [6]. Therefore, lignin can not only form a shield to prevent carbohydrate from the enzyme attack [7], but also adsorb cellulase enzymes nonproductively and irreversibly via hydrophobic, electrostatic, and hydrogen bond interactions, making it undesirable for enzymatic digestion of biomass $[8,9]$. Although the lignin shield can be disrupted by the biomass pretreatment and lignin can be usually partially removed, a considerable part of residual lignins still remain in the pretreated substrates. And the complete removal of lignin, the term "delignification", is costly and difficult for the existing thermochemical pretreatment technologies. As a result, the nonproductive binding between lignin and cellulase enzymes was unavoidable and led to the decrease of glucose release in the enzymatic hydrolysis process.

How to reduce the cellulase-lignin interaction for enhancing the enzymatic saccharification efficiency has been widely studied. The anionic surfactant and hydrophobic proteins, as lignin blocker, had been reported to be effective to weaken or eliminate the nonproductive adsorption by blocking the exposed sites of lignin surfaces, thereby decreasing the cellulase activity loss $[10,11]$. Lignosulfonate (LS) can improve the cellulolytic hydrolysis efficiency due to the increase of negative charges, and further lead to the increase of free enzyme content in supernatant [12]. Certain metal ions, such as $\mathrm{Ca}^{2+}$ and $\mathrm{Mg}^{2+}$, might also occupy the active sites of lignin and form lignin-metal complex, which blocked the interaction between cellulase and lignin [13, 14]. The free phenolic hydroxyls in lignin matrix can decrease enzymatic hydrolysis efficiency of lignocellulose by forming hydrogen bonding with cellulase enzymes, but the inhibitory effect could be removed by lignin hydroxypropylation $[15,16]$. It had also found that the presence of carboxylic groups in lignin might reduce the negative effects of lignin on enzymatic hydrolysis of pretreated substrates by increasing hydrophilicity and electrostatic repulsion against enzymes [17]. Lignin S/G ratios may significantly influence sugar release of lignocellulosic biomass $[18,19]$. In addition, genetic engineering had been explored to modify the pathways of lignin biosynthesis to decrease lignin content and alter the relative proportions of lignin subunit (G, S, and H units) [20-22]. These evidences clearly indicated that the nonproductive binding of enzymes to lignin can greatly attribute to the interaction between lignin functional groups and the cellulase protein.

The primary goal of this work is to modify the surface properties and structure of residual lignin through introducing functional groups, which have potential for reducing the cellulase-lignin interaction. Modified lignin preparations, including sulfonated lignin (SL), oxidized lignin (OL) and carboxylic lignin (CL), were prepared from alkali lignin (AL), and their structural properties were thoroughly investigated by FTIR, 13C, 2D HSQC NMR, and XPS analysis. The phenolic hydroxyl group content, the amount of negative charges and contact angle of lignin preparations were measured, respectively. The Langmuir adsorption isotherm was used to characterize enzyme affinity to lignin preparations. Finally, the effect of modified lignins on the enzymatic digestion of cellulose were evaluated and compared; whether the lignin modification as post-treatments can work on lignocellulosic biomass was also investigated.

\section{Results and discussions}

\section{Structural characteristic of lignin preparations}

The FTIR, ${ }^{13} \mathrm{C}$ and $2 \mathrm{D}$ HSQC NMR were used to characterize the chemical structure of lignin preparations. The fingerprint region $\left(800-1800 \mathrm{~cm}^{-1}\right)$ of FTIR spectra, corresponding to the stretching vibrations of different groups in lignin preparations, is displayed in Fig. 1, and the bands are assigned in Table 1 based on the previous studies [23, 24]. As shown in Fig. 1, obvious characteristic peaks at 1616,1512 , and $1423 \mathrm{~cm}^{-1}$ observed in all samples were the aromatic skeletal vibrations, implying that the core of lignin structure was not altered significantly during the modified process. However, the spectra also showed some changes in the peaks and the absorption intensities. The peak at $1708 \mathrm{~cm}^{-1}$ characteristic of non-conjugated carbonyl groups is much more intense in $\mathrm{AL}$ than OL. And even such a band was not present in SL and CL. It could be due to the carboxyl or ester linkage of $\mathrm{C}_{\gamma}$ in AL side chain was partially cleaved during the modification process. The absorption band of $1649 \mathrm{~cm}^{-1}$, assigned to conjugated carbonyl groups, was identified in SL, OL, and CL. The intensity of $1272 \mathrm{~cm}^{-1}$ corresponding to the $\mathrm{C}-\mathrm{O}$ stretching of $\mathrm{G}$ type lignin had not been significantly changed after modifications. The signal intensity of $p$-hydroxyphenyl units ( $\mathrm{H}$ unit) at $834 \mathrm{~cm}^{-1}$ was reduced in modified lignin, compared with that of $\mathrm{AL}$, indicating the dissolving of $\mathrm{H}$-type lignin. As compared to $\mathrm{AL}, \mathrm{OL}$, and $\mathrm{CL}$, the successful introduction of the sulfonic groups into SL can be justified by the stronger bands at $1043 \mathrm{~cm}^{-1}$ ( $\mathrm{S}=\mathrm{O}$ stretching vibration) and $536 \mathrm{~cm}^{-1}$ (C-S stretching vibration).

In the ${ }^{13} \mathrm{C}$ NMR spectra (Fig. 2) and the assignment of correlation signals (Table 2) of lignin, the 


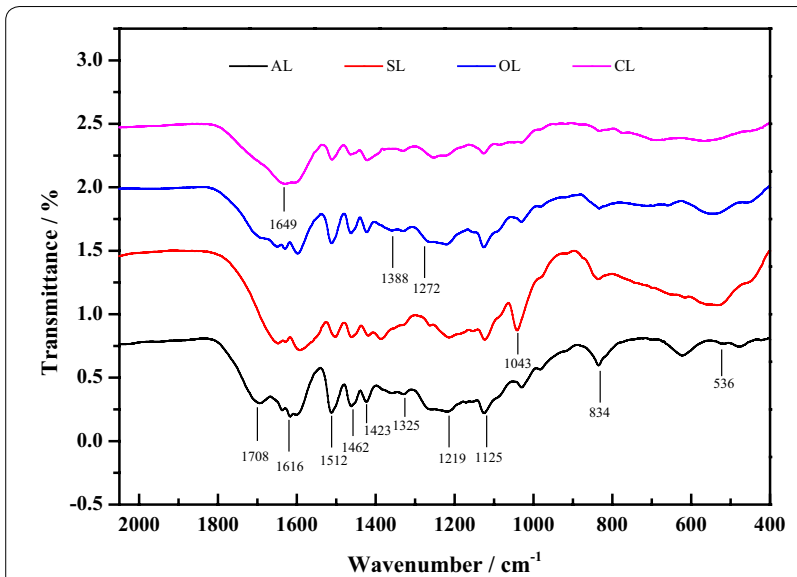

Fig. 1 FTIR spectra of lignin samples. Alkali lignin, sulfonated lignin, oxidized lignin, and carboxylated lignin were expressed as $\mathrm{AL}, \mathrm{SL}, \mathrm{OL}$, and $\mathrm{CL}$, respectively

Table 1 Assignments of FTIR peaks in lignin samples [23, 24]

\begin{tabular}{ll}
\hline Wavenumber/cm & Assignments \\
\hline $1616,1512,1423$ & Aromatic skeletal vibrations \\
1708 & Non-conjugated carbonyl groups \\
1649 & Conjugated carbonyl groups \\
1272 & The C-O stretching of G type lignin \\
1043 & S=O stretching vibration \\
834 & p-hydroxyphenyl units (H unit) \\
536 & C-S stretching vibration \\
\hline
\end{tabular}

aromatic structure region (103-162 ppm) was easily identified by correlation signal at 110.6, 115.6, 119, 103, and $152.3 \mathrm{ppm}$, respectively, corresponding to $\mathrm{G}_{2}, \mathrm{G}_{5}, \mathrm{G}_{6}$, $S_{2,6}$, and $S_{3,5}$ positions $[25,26]$. As shown in Fig. 2 , the signal intensities of $S_{3,5}$ units and $S_{2,6}$ in three modified lignins were greatly decreased compared to those of AL, and the intensities of $G_{2}, G_{5}$, and $G_{6}$ units also showed a similar trend with $\mathrm{S}$ units. The $p$-hydroxyphenyl $(\mathrm{H})$ units occurred as two signals at 128.0 and $129.2 \mathrm{ppm}$ (C-2/C-6); and the lignin sulfonation, oxidation and carboxylation can reduce the level of $\mathrm{H}$-lignin unit. The transformation of above signals indicated that lignin polymer was dissociated and the modification can improve the hydrophilicity and solubility of lignin due to altering the relative proportions of lignin subunit $(G, S$, and $\mathrm{H}$ units). Moreover, the bands of condensed aromatics (140-123 ppm) became weak and narrow in SL, OL, and CL compared to those in AL, implying that fewer condensation reactions could occur between free lignin units during the modification. The signal intensities between 50 and $90 \mathrm{ppm}$ corresponding to lignin interunit linkages had no changes, suggested that the modification could occur on the surface of lignin moieties. The decreasing signal intensities for $-\mathrm{OCH}_{3}$ can be seen at $56.5 \mathrm{ppm}$, implying that the modification reactions could cause demethoxylation and demethylation in AL. In addition, the aliphatic COOR at 178-168 ppm are more abundant in $\mathrm{CL}$, followed by OL and SL. In the carboxylation reaction, the $\mathrm{H}$ atom in lignin hydroxyl was substituted by the $-\mathrm{OCH}_{2} \mathrm{COOR}$, which could be responsible for the most abundant aliphatic COOR.

To further structural investigation, the 2D HSQC NMR was used to analyze the structural units and different interunit linkages of lignin polymers. The HSQC spectra consisted of the side chain $\left(\delta_{\mathrm{C}} / \delta_{\mathrm{H}} 50-95 / 2.5-6.0\right)$ and aromatic regions $\left(\delta_{\mathrm{C}} / \delta_{\mathrm{H}} 95-160 / 5.5-8.50\right)$ and correlation signals are assigned in Table 3 according to previous publications [26, 27].

In the side-chain regions, the $\beta-O-4^{\prime}$ aryl ether $(\mathrm{A})$ and methoxyl groups $\left(\delta_{\mathrm{C}} / \delta_{\mathrm{H}} 55.4 / 3.72\right)$ are the most prominent signals observed in all spectra. The signals at $\delta_{\mathrm{C}} / \delta_{\mathrm{H}}$ 71.6/4.88 $\left(A_{\alpha}\right), \delta_{\mathrm{C}} / \delta_{\mathrm{H}} 82.8-85.7 / 4.13-4.46\left(A_{\beta}(\mathrm{G})\right.$ and $\left.A_{\beta}(\mathrm{S})\right)$, and $\delta_{\mathrm{C}} / \delta_{\mathrm{H}} 59.5-59.7 / 3.40-3.63\left(A_{\gamma}\right)$ belong to the $\mathrm{C}_{\alpha}-\mathrm{H}_{\alpha}, \mathrm{C}_{\beta}-\mathrm{H}_{\beta}$, and $\mathrm{C}_{\gamma}-\mathrm{H}_{\gamma}$ correlations of the $\beta-O-4^{\prime}$ ether substructures, respectively. As shown in Fig. 3, the corresponding correlations of $A_{\alpha}$ and $A_{\beta}$ were still detected and no changes occurred in all samples. However, it was interesting that by comparison with AL, three modified lignins exhibited the absorption of intense signals at $\delta_{\mathrm{C}} / \delta_{\mathrm{H}} 59.5-63.5 .7 / 3.40-3.83\left(A_{\gamma}\right)$. This phenomenon suggested that the AL has been modified at the acylated $\gamma$-carbon in $\beta-O-4^{\prime}$ aryl ether linkages of the side chains. And $\beta-\beta^{\prime}, \beta-1^{\prime}$ and $\beta-5^{\prime}$ substructures were not also observed in the spectra of modified lignin, suggesting that the surface modification of lignin could not cause the condensation between lignin units. Aromatic regions of the HSQC spectra can give basic correlation signals of the $p$-hydroxyphenyl $(\mathrm{H})$, guaiacyl $(\mathrm{G})$, and syringyl (S) lignin units. Specifically, the $\mathrm{C}_{2,6}-\mathrm{H}_{2,6}$ correlations signals of $\mathrm{S}$ and $\mathrm{C}_{\alpha}$-oxidized $\mathrm{S}\left(\mathrm{T}^{\prime}\right)$ units were shown at $\delta_{\mathrm{C}} / \delta_{\mathrm{H}} 103.8 / 6.69$ and $\delta_{\mathrm{C}} / \delta_{\mathrm{H}} 106.4 / 7.31$. In Fig. 3, the signal intensity of $\mathrm{C}_{2,6}-\mathrm{H}_{2,6}$ in $\mathrm{S}$ unit tended to reduce in the modified samples compared to that of the control AL, indicating a decrease of $S$ units in the surface of modified lignins, which was due to the cleavage of $\beta-O-4$ linkage. Similarly, the $\mathrm{C}_{5}-\mathrm{H}_{5}, \mathrm{C}_{2}-\mathrm{H}_{2}$, and $\mathrm{C}_{6}-\mathrm{H}_{6}$ correlations in $\mathrm{G}$ units, at $\delta_{\mathrm{C}} / \delta_{\mathrm{H}} 115.1 / 6.72, \delta_{\mathrm{C}} / \delta_{\mathrm{H}} 111.0 / 7.02$, and $\delta_{\mathrm{C}} / \delta_{\mathrm{H}} 119.0 / 6.77$, respectively, were observed in very low intensities for three modified lignins. It is worth mentioning that $p$-hydroxyphenyl $(\mathrm{H})$ units exhibited the strong signal for $\mathrm{C}_{2,6}-\mathrm{H}_{2,6}$ at $\delta_{\mathrm{C}} / \delta_{\mathrm{H}} 127.5 / 7.23$ in others lignin, while it was weak in OL due to that oxidation treatment can result in less $\mathrm{H}$ units than that of other lignin samples. The above findings to aromatic ring units 


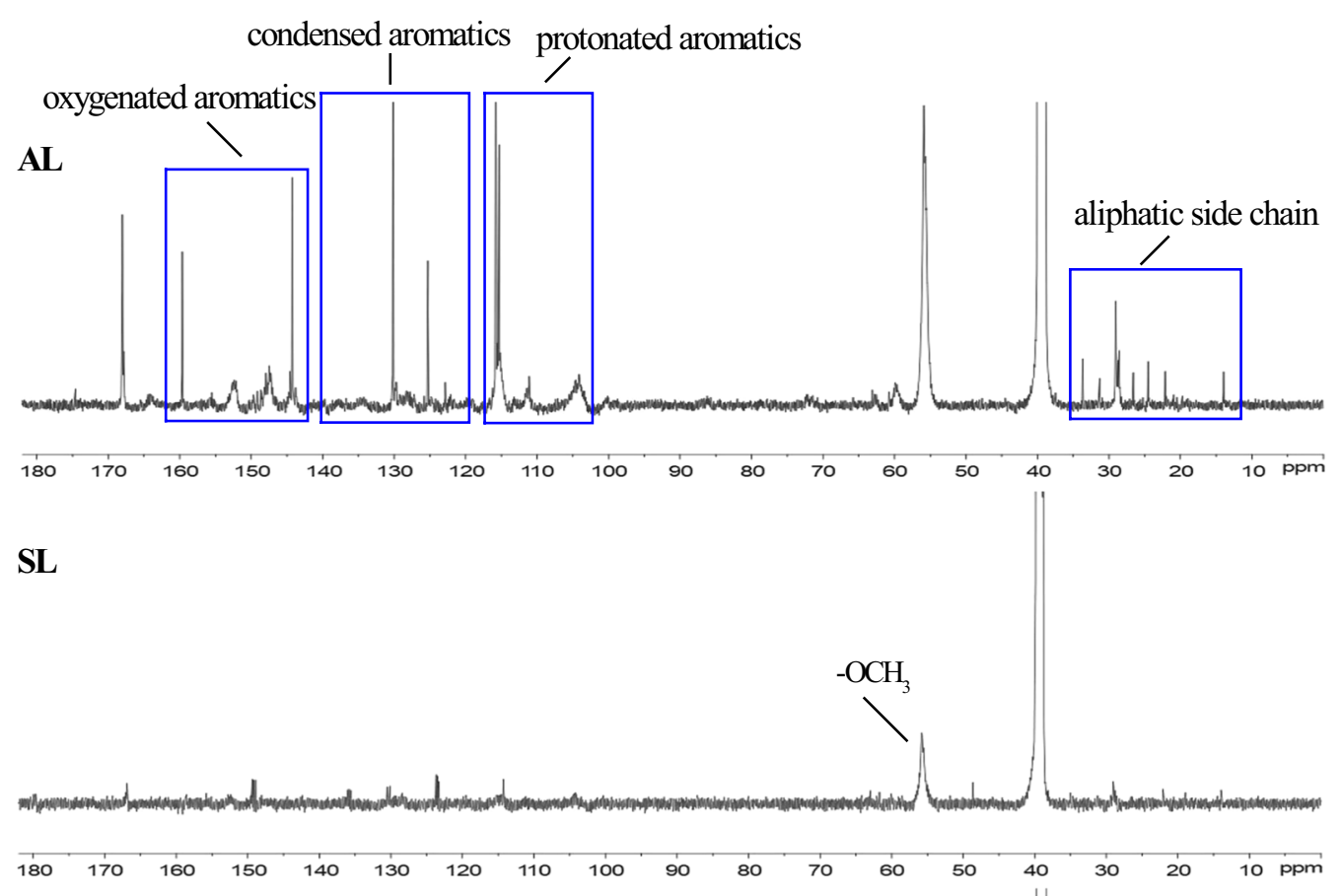

OL

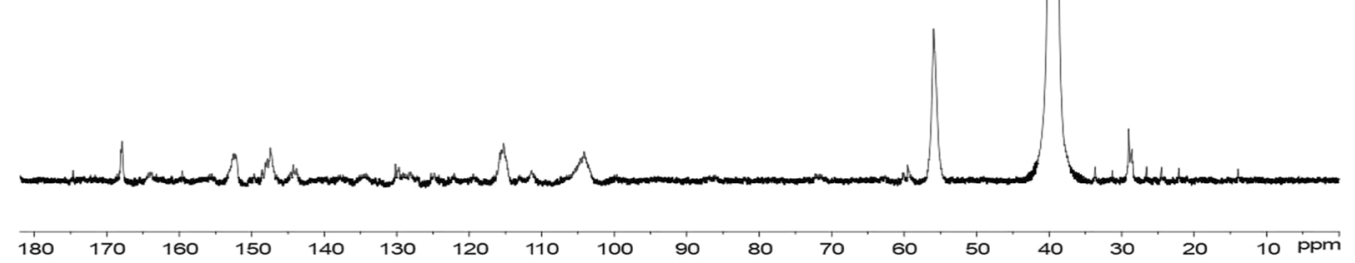

CL aliphatic COOR

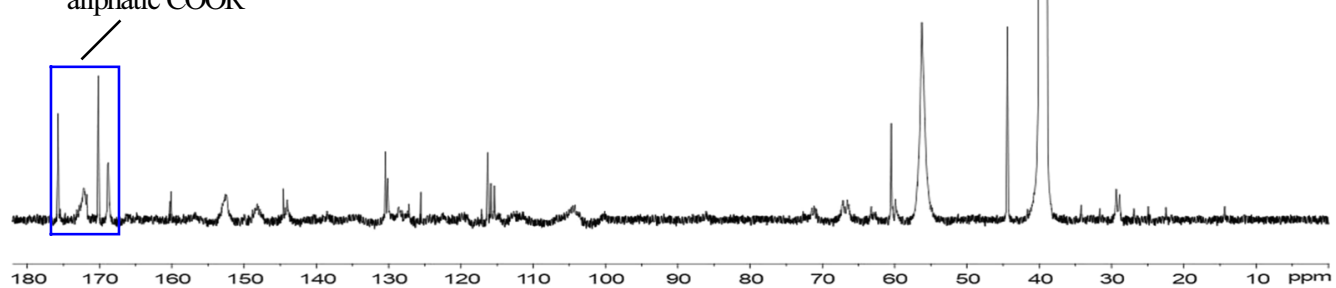

Fig. $2{ }^{13} \mathrm{C}$ NMR spectra of lignin samples

of lignin are consistent with FTIR analyses. In addition, the $\mathrm{C}_{2}-\mathrm{H}_{2}, \mathrm{C}_{6}-\mathrm{H}_{6}$, and $\mathrm{C}_{7}-\mathrm{H}_{7}$ correlations signals of ferulic acid (FA) were clearly observed at $\delta_{\mathrm{C}} / \delta_{\mathrm{H}} 110.8 / 7.35$, $123.1 / 7.16$, and $144.4 / 7.42$ in the spectra. Alkali lignin showed a higher proportion of FA, but the intensity of FA signals could be weakened after the oxidized and carboxylic reaction, and it disappeared after sulfonated reaction. Simultaneously, the relatively strong signals at the $\delta_{\mathrm{C}} / \delta_{\mathrm{H}}$ $129.8 / 7.52,143.9 / 7.51$, and $115.0 / 6.24$, corresponding to p-coumarates (pCA) were presented in all lignin samples except for SL; however, in comparison with AL, pCA units of oxidized (OL) and carboxylic lignin (CL) samples showed a slightly decrease. It had suggested that $p$-coumaric and acid ferulic acid are associated with the lignin monomer through either $\mathrm{C}-\mathrm{C}$ or ether linkages and the carboxylic groups were not in free but in ester form [2831]. This implied that pCA and FA in AL could be partly or completely hydrolyzed in the modification, and these 
Table 2 Signal assignments of lignin samples in the ${ }^{13} \mathrm{C}$ NMR spectrum $[25,26]$

\begin{tabular}{llll}
\hline $\boldsymbol{\delta}$ (ppm) & Assignments & $\boldsymbol{\delta}$ (ppm) & Assignments \\
\hline $178-168$ & Aliphatic COOR & 115.6 & $\mathrm{C}_{5}$ in G unit \\
152.3 & $\mathrm{C}_{3} / \mathrm{C}_{5}$ in S unit & 110.6 & $\mathrm{C}_{2}$ in G unit \\
$140-123$ & Condensed aromatics & 103 & $\mathrm{C}_{2,6}$ in S unit \\
129.2 & $\mathrm{C}_{6}$ in H unit & $50-90$ & Interunit linkages \\
128 & $\mathrm{C}_{2} / \mathrm{C}_{6} \mathrm{H}$ unit & & $\left(\beta-\beta^{\prime}, \beta-5\right.$ and $\left.\beta-O-4^{\prime}\right)$ \\
119 & $\mathrm{C}_{6} / \mathrm{C}_{5}$ in G unit & 56.5 & $\mathrm{OCH}_{3}$ in G and S unit \\
\hline
\end{tabular}

G: guaiacyl unit, $\mathrm{S}$ : syringyl unit, $\mathrm{H}$ : $p$-hydroxyphenyl unit

groups could be broken into shorter side-chain products, such as vinyl phenols [32].

\section{Surface properties of lignin preparations}

The XPS analysis can provide some knowledge about the elemental composition and functional group abundances on the near-surface regions of materials [33, 34]. As seen in Table 4, carbon and oxygen were the predominant elements detected on the all samples. Besides the two elements, the SL obtained from the sulfonation reaction contains sodium $(7.17 \%)$ and sulfur $(4.46 \%)$ and CL from carboxylation reaction has sodium $(3.09 \%)$ and chlorinum $(1.83 \%)$ element on the surface. As expected, the $\mathrm{O} / \mathrm{C}$ ratios of SL, OL, and CL were $0.43,0.35$, and 0.38 , respectively, and distinctively higher than that of $\mathrm{AL}$, 0.28 , suggesting that the surfaces of particles could have been altered after modification reaction. This lead to the conclusion that oxygen element could appear as free or esterified hydroxyl groups and free or esterified carboxyl groups in modified lignins. Moreover, XPS measurement also can give the information on functional groups of the sample surface. Especially, the abundance of $\mathrm{C}-\mathrm{C}$ and $\mathrm{C}-\mathrm{H}$ bonds $(284.6 \mathrm{eV})$ decreased from $56.57 \%$ for AL to $54.90 \%$ for CL, $52.58 \%$ for OL and $38.29 \%$ for SL, suggesting that the decrease of condensation degree in lignin after the modification reactions. Quantities of $-\mathrm{C}-\mathrm{O}-$ bonds on the surface of $\mathrm{CL}$ and SL were 33.13 and $7.29 \%$, respectively, which were lower than in $\mathrm{AL}$ (39.65\%) and OL (39.84\%). A significant increase of carbon atoms bonded with carbonyl or non-carbonyl oxygen $(\mathrm{O}-\mathrm{C}=\mathrm{O}, 289 \mathrm{eV})$ in modified samples, $\mathrm{OL}$ and $\mathrm{CL}$, was also observed and the amount of $\mathrm{O}-\mathrm{C}=\mathrm{O}$ bonds on the surface of $\mathrm{OL}$ and $\mathrm{CL}$ were $1-2.17$ times higher than that of AL. This will be beneficial to increase the hydrophilicity of modified lignins. Although the content of $-\mathrm{C}-\mathrm{O}-$ and $\mathrm{O}-\mathrm{C}=\mathrm{O}$ bonds on SL surface was much lower than those of $\mathrm{AL}$, the sulfonate groups in SL, incorporated by sulfonation reaction, were hydrophilic groups, thus the surface of SL had hydrophilicity.

The total concentration of free phenolic groups in all lignins using the $\mathrm{F}-\mathrm{C}$ method is listed in Table 5. The phenolic group content in SL, OL, and CL were estimated to be $0.56,0.91$, and $0.21 \mathrm{mmol} / \mathrm{g}$, respectively. By comparison with AL of $1.09 \mathrm{mmol} / \mathrm{g}$, the modified lignins showed lower $\mathrm{Ph}-\mathrm{OH}$ content, indicating the sulfonated, oxidized, and carboxylation modification could contribute to the decrease of phenolic group content in lignin preparations. The content of free phenolic groups in modified lignins decreased by about $17-91 \%$ compared with AL. It

Table 3 Assignments of ${ }^{13} \mathrm{C}-{ }^{1} \mathrm{H}$ correlation signals in the HSQC spectrum of lignin samples [26, 27]

\begin{tabular}{|c|c|c|}
\hline Signals & $\delta_{\mathrm{C}} / \delta_{\mathrm{H}}$ & Assignments \\
\hline $\mathrm{MeO}$ & $55.4 / 3.72$ & $\mathrm{C}-\mathrm{H}$ in methoxyls \\
\hline$A_{\gamma}$ & $59.5-59.7 / 3.40-3.63$ & $C_{\gamma}-H_{\gamma}$ in $\beta-O-4^{\prime}$ substructures (A) \\
\hline$A_{a}$ & $71.6 / 4.88$ & $\mathrm{C}_{a}-\mathrm{H}_{a}$ in $\beta-O-4^{\prime}$ substructures linked to a $\mathrm{S}$ unit (A) \\
\hline$A_{\beta(G)}, A_{\beta(S)}$ & $82.8-85.7 / 4.13-4.46$ & $\begin{array}{l}C_{\beta}-H_{\beta} \text { in } \beta-O-4^{\prime} \text { substructures linked to a } \mathrm{G} \text { unit (A) } \\
C_{\beta}-H_{\beta} \text { in } \beta-O-4^{\prime} \text { substructures linked to a } S \text { unit (A) }\end{array}$ \\
\hline$S_{2,6}$ & 103.8/6.69 & $\mathrm{C}_{2,6}-\mathrm{H}_{2,6}$ in etherified syringyl units (S) \\
\hline$S_{2,6}^{\prime}$ & $106.4 / 7.31$ & $\mathrm{C}_{2,6}-\mathrm{H}_{2,6}$ in oxidized $\left(\mathrm{C}_{a}=\mathrm{O}\right)$ phenolic syringyl units $\left(\mathrm{S}^{\prime}\right)$ \\
\hline $\mathrm{G}_{5}$ & $115.1 / 6.72$ & $\mathrm{C}_{5}-\mathrm{H}_{5}$ in guaiacyl units $(\mathrm{G})$ \\
\hline $\mathrm{G}_{2}$ & 111.0/7.02 & $\mathrm{C}_{2}-\mathrm{H}_{2}$ in guaiacyl units $(\mathrm{G})$ \\
\hline $\mathrm{G}_{6}$ & 119.0/6.77 & $\mathrm{C}_{6}-\mathrm{H}_{6}$ in guaiacyl units $(\mathrm{G})$ \\
\hline $\mathrm{FA}_{2}$ & $110.8 / 7.35$ & $\mathrm{C}_{2}-\mathrm{H}_{2}$ in FA \\
\hline $\mathrm{FA}_{6}$ & $123.1 / 7.16$ & $\mathrm{C}_{6}-\mathrm{H}_{6}$ in FA \\
\hline $\mathrm{FA}_{7}$ & $144.4 / 7.42$ & $\mathrm{C}_{7}-\mathrm{H}_{7}$ in $\mathrm{FA}$ \\
\hline \multirow[t]{2}{*}{$\begin{array}{l}\mathrm{H}_{2,6} \\
p C A\end{array}$} & $\begin{array}{l}127.5 / 7.23 \\
129.8 / 7.52 \\
143.9 / 7.51\end{array}$ & $\begin{array}{l}\mathrm{C}_{2,6}-\mathrm{H}_{2,6} \text { in } \mathrm{H} \text { units }(\mathrm{H}) \\
\mathrm{C}_{2,6}-\mathrm{H}_{2,6} \text {-coumaroylated substructures }(p C A) \\
\mathrm{C}_{a^{\prime}}-\mathrm{H}_{a^{\prime}}, \mathrm{p} \text {-coumaroylated substructures }(p C A)\end{array}$ \\
\hline & $115.0 / 6.24$ & $\mathrm{C}_{\beta}-\mathrm{H}_{\beta^{\prime}} p$-coumaroylated substructures ( $\left.p C A\right)$ \\
\hline
\end{tabular}

G: guaiacyl unit; S: syringyl unit; $\mathrm{H}$ : $p$-hydroxyphenyl unit; $\mathrm{pCA}$ : $p$-coumaric acid; FA: ferulic acid 

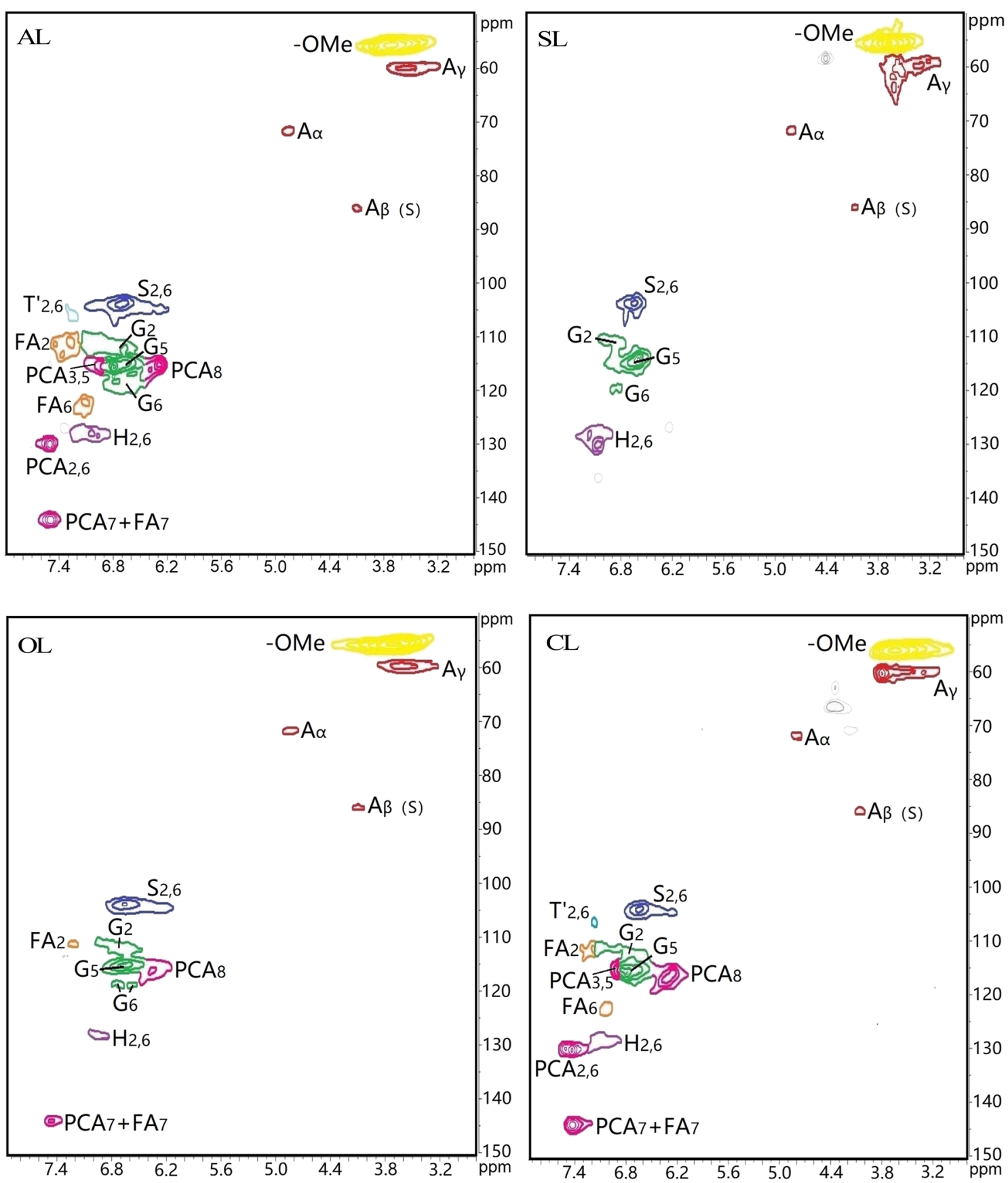

Fig. 3 2D-HSQC NMR spectra of lignin samples

suggested that the AL fractions were obtained by alkali extraction under sharp condition, which can produce high phenolic content by the cleavage of ether bonds. The measurements of contact angle against water were carried out to reveal the hydrophobic character of lignin surface. As can be seen in Table 5, the contact angles decreased very quickly with the introduction of hydrophilic functional groups and units. The AL exhibited a contact angle with water of $98.7^{\circ}$, while those of SL, OL, and CL were $29.4^{\circ}, 29.5^{\circ}$, and $38.2^{\circ}$, respectively, suggesting that three modified lignins had stronger relative hydrophilicity and permittivity. The surface structural differences between AL and modified lignins can account for this result, because there 
Table 4 Elemental composition and functional groups based on the C1s peaks by XPS analysis

\begin{tabular}{|c|c|c|c|c|c|c|c|c|}
\hline \multirow[t]{2}{*}{ Samples } & \multicolumn{5}{|c|}{ Element composition (\%) } & \multicolumn{3}{|c|}{ Surface chemical groups (\%) } \\
\hline & $\mathrm{C}$ & 0 & $\mathrm{Na}$ & $\mathrm{S} / \mathrm{CL}$ & $\mathrm{O} / \mathrm{C}$ ratio & $\begin{array}{l}\text { C-C/C-H (284.6, } \\
\text { eV) }\end{array}$ & $\mathrm{C}-\mathrm{O}(286.6, \mathrm{e} \mathrm{V})$ & $\begin{array}{l}\mathrm{O}-\mathrm{C}=\mathrm{O} \\
(289, \mathrm{eV})\end{array}$ \\
\hline$A L$ & 78.14 & 21.86 & / & / & 0.28 & 56.57 & 39.65 & 3.78 \\
\hline SL & 61.75 & 26.62 & 7.17 & $4.46(S)$ & 0.43 & 38.29 & 7.29 & 2.45 \\
\hline $\mathrm{OL}$ & 74.27 & 25.73 & / & / & 0.35 & 52.58 & 39.84 & 7.58 \\
\hline$C L$ & 69.05 & 26.06 & 3.09 & $1.83(\mathrm{CL})$ & 0.38 & 54.90 & 33.13 & 11.98 \\
\hline
\end{tabular}

Table 5 Water contact angles, Zeta potentials and phenolic group content in lignin samples

\begin{tabular}{lcll}
\hline Samples & $\begin{array}{l}\text { Zeta potential } \\
(\mathbf{m V})\end{array}$ & $\begin{array}{l}\text { Contact angle } \\
\left.\mathbf{(}^{\circ}\right)\end{array}$ & $\begin{array}{l}\text { Phenolic group } \\
\text { content }(\mathbf{m m o l} / \mathbf{g})\end{array}$ \\
\hline $\mathrm{AL}$ & 3.5 & 98.7 & 1.09 \\
$\mathrm{SL}$ & -45.9 & 29.4 & 0.56 \\
$\mathrm{OL}$ & -21.5 & 29.5 & 0.91 \\
$\mathrm{CL}$ & -27.3 & 38.2 & 0.213 \\
\hline
\end{tabular}

was a higher increase of $p$-coumaric, acid ferulic acid, sulfonate groups, and aliphatic COOR, and a decrease of condensation degree and S-lignin, G-lignin unit in the modified lignins. The results were further indication that the sulfonated, oxidized, and carboxylation modification of lignin could be used to adjust lignin chemical functionality and surface hydrophilicity. Zeta potential values of all lignin samples were measured and are compared in Table 5. The zeta potential of AL was determined to be $3.5 \mathrm{mV}$, suggesting that not only no repulsion existed, but there was attractive force between negative charged proteins and AL. However, the zeta potential values of three modified lignins was negative, $-21.5 \mathrm{mV}$ for $\mathrm{OL},-27.3 \mathrm{mV}$ for $\mathrm{CL}$, and $-45.9 \mathrm{mV}$ for SL, respectively. And the SL displayed 0.7-1.1 times higher zeta potential than CL and OL due to sulfonic groups. So, the higher negative zeta potential of SL, OL, and CL would cause stronger electrostatic repulsion between modified lignins and negative charged proteins in cellulase enzymes.

\section{Effects of alkaline lignin modification on nonproductive adsorption of cellulase}

To examine how the modification in $\mathrm{AL}$ interfered the cellulase-lignin interaction, the cellulase adsorption on lignin samples and Langmuir adsorption isotherms of cellulase enzymes were analyzed and are summarized in Fig. 4 and Table 6. The AL had the highest affinity for cellulase $(5.92 \mathrm{~mL} / \mathrm{mg}$ protein), whereas SL had the lowest affinity $(1.16 \mathrm{~mL} / \mathrm{mg}$ protein) for

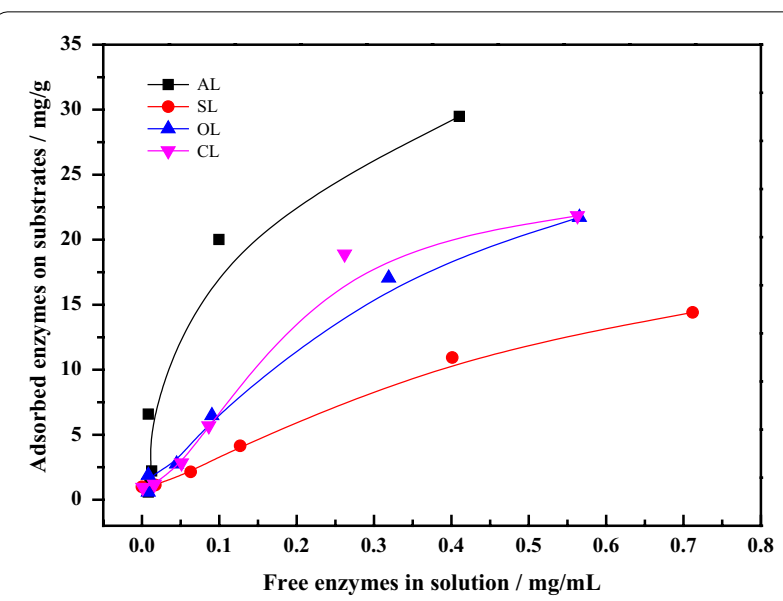

Fig. 4 Cellulase enzyme adsorption on modified lignins. Lignins and enzyme cellulases $(0.01-2 \mathrm{mg} / \mathrm{mL})$ were incubated in $0.05 \mathrm{M}$ citrate buffer at $4{ }^{\circ} \mathrm{C}$ and $150 \mathrm{rpm}$ for $3 \mathrm{~h}$ to reach equilibrium

cellulase, followed by $\mathrm{OL}(2.25 \mathrm{~mL} / \mathrm{mg}$ protein $)$ and $\mathrm{CL}$ (2.72 $\mathrm{mL} / \mathrm{mg}$ protein). Similarly, the distribution coefficient $\left(R=K \times \Gamma_{\mathrm{m}}\right)$ of cellulase on $\mathrm{AL}$ that represented the binding strength of lignin to cellulase enzymes was $0.253 \mathrm{~L} / \mathrm{g}$ lignin, which was two to threefolds higher than those on SL $(R=0.083 \mathrm{~L} / \mathrm{g})$, OL $(R=0.089 \mathrm{~L} / \mathrm{g})$ and $\mathrm{CL}$ $(R=0.104 \mathrm{~L} / \mathrm{g})$. It was noticed that the binding strength of $\mathrm{AL}(R=0.253 \mathrm{~L} / \mathrm{g})$ was even higher than that of Avicel $(R=0.133 \mathrm{~L} / \mathrm{g})$, suggesting that $A L$ would get more chance to adsorb cellulase enzyme than cellulose. Consequently, after modification reaction, the maximum adsorption capacity of lignin toward enzymes was significantly reduced. Specifically, AL $\left(\Gamma_{\mathrm{m}}=42.78 \mathrm{mg} / \mathrm{g}\right.$ lignin $)$ had stronger adsorption capacity, which can adsorb about $7.9-24 \%$ more protein than modified lignins. And the maximum adsorption capacity of modified lignins decreased in the order $\mathrm{OL}>\mathrm{CL}>\mathrm{SL}$, among which sulfonic acid groups caused greater decrease in the binding strength than the oxidized and carboxylate groups. This was probably because the introduction of sulfonic groups could consume more phenolic hydroxyls and bring more negative charges in lignin moieties to some extent. 
Table 6 Langmuir adsorption isotherm parameters from enzyme adsorption on substrates

\begin{tabular}{llll}
\hline Substrates & $\boldsymbol{\Gamma}_{\mathbf{m}}(\mathbf{m g} \mathbf{g})$ & $\boldsymbol{K}(\mathbf{m L} / \mathbf{m g})$ & $\boldsymbol{R}(\mathbf{L} / \mathbf{g})$ \\
\hline Avicel & 48.57 & 2.74 & 0.133 \\
AL & 42.78 & 5.92 & 0.253 \\
SL & 32.43 & 1.16 & 0.038 \\
OL & 39.41 & 2.25 & 0.089 \\
CL & 38.12 & 2.72 & 0.104 \\
\hline
\end{tabular}

We believe that the decrease of cellulase-lignin interaction was related to the structure and physicochemical properties of modified lignins. As well known, the hydrophobic, electrostatic, and hydrogen-bonding interactions could mediate the nonproductive adsorption of cellulase onto lignin. Alkali lignin had a contact angle of $98.7^{\circ}$ and the binding strength of $0.253 \mathrm{~L} / \mathrm{g}$ lignin. The modification led to a decrease in contact angle of lignin by $61-70 \%$, due to the drop in the degree of condensation and lignin subunits, such as syringyl $(\mathrm{S})$ and guaiacyl $(\mathrm{H})$, and the more exposed carboxylic groups. This can make the lignin more hydrophilic, thereby decreasing the nonproductive binding for cellulase. In addition, the functional groups introduced into AL also had a much greater impact on the surface charge of lignin moieties and the formation of hydrogen bonds. According to XPS analysis $(\mathrm{O}-\mathrm{C}=\mathrm{O}, 289 \mathrm{eV})$ and C13 NMR (178-168 ppm), a low content of carboxylic groups was introduced to the $\mathrm{CL}$ and OL surface, and the abundant of sulfonic acid groups also was incorporated into SL in the FTIR $(\mathrm{S}=\mathrm{O}$ stretching vibration, $1043 \mathrm{~cm}^{-1}$ ), thus the zeta potential values of modified lignin were increased from $3.5 \mathrm{eV}$ (AL) to
$-21.5 \mathrm{eV}(\mathrm{OL}),-27.3 \mathrm{eV}(\mathrm{CL})$ and $-45.9 \mathrm{eV}(\mathrm{SL})$, which increased the electrostatic repulsion between enzyme and lignin and prevented the nonproductive binding. And with the consumption of phenolic hydroxyl groups in the sulfonation, oxidation, and carboxylation, the content of phenolic hydroxyls decreased by 49,17 , and $80 \%$, respectively, comparing to AL. This meant the decrease of binding strength between cellulase and modified lignins, because the cellulase adsorption on lignin correlated positively with phenolic hydroxyl content $[15,16]$. As a result, the hydrophobic, electrostatic and hydrogenbonding interactions together had exerted synergistic effects upon weakening the nonproductive adsorption of cellulase onto modified lignins, led to the affinity constants and binding strengths decrease by $59-85 \%$ than $\mathrm{AL}$, which would stimulate the enzymatic digestion of cellulose.

\section{Effects of alkaline lignin modification on glucose yield and cellulase activity in enzymatic saccharification of Avicel}

As showed in Fig. 5, all lignin preparations had a great inhibitory effect on the $72 \mathrm{~h}$ glucose yield of Avicel, which were consistent with the above the enzymatic adsorption data. The enzymatic saccharification of Avicel with lignin loading of $4 \mathrm{~g} / \mathrm{L}$ was evaluated in Fig. 5a. For the hydrolysis of pure cellulose, Avicel, the $72 \mathrm{~h}$ glucose yield was $57.4 \%$. As can be seen in Fig. 5a, although all of lignin preparations displayed the inhibition compared with pure cellulose, the addition of modified lignins obviously reduced the negative effect on enzymatic hydrolysis. The $72 \mathrm{~h}$ glucan conversion with addition of AL was $44.5 \%$, while the glucan conversion at $72 \mathrm{~h}$ with addition of SL,
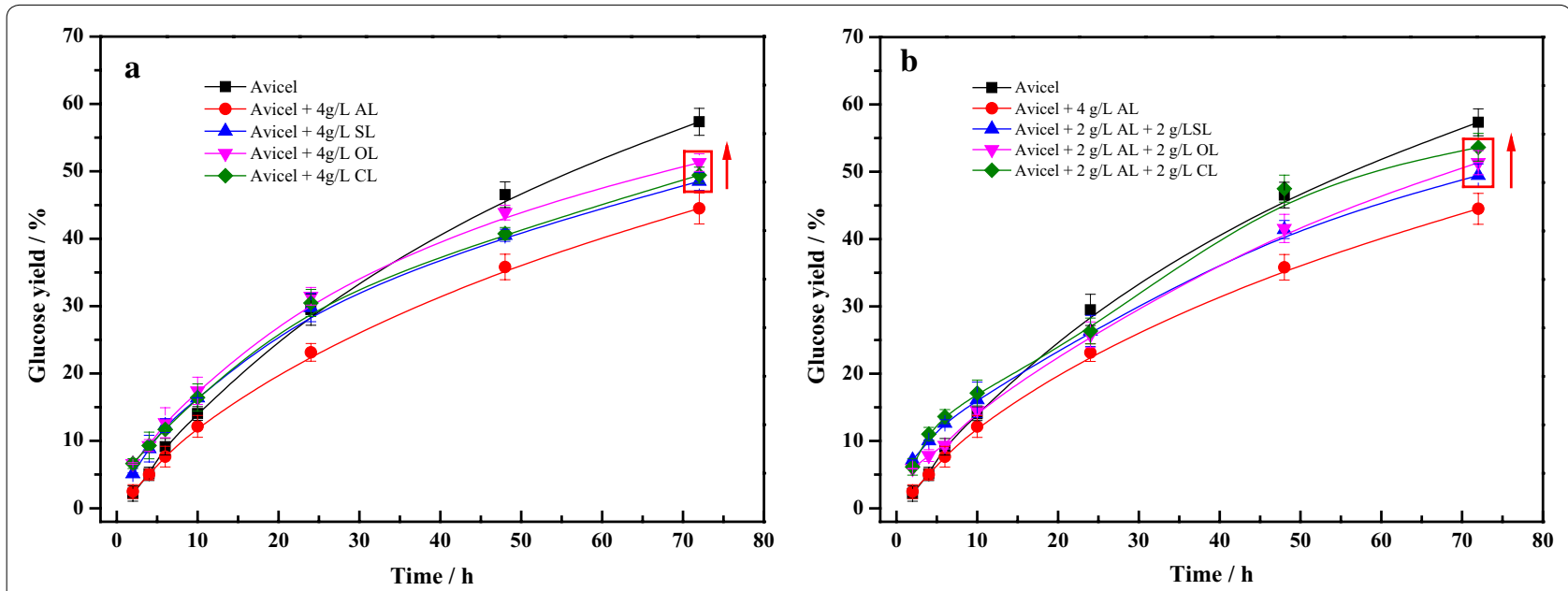

Fig. 5 Effects of modified lignins on glucose yield in enzyme saccharification of Avicel. a Enzymatic saccharification of Avicel with lignin loading of $4 \mathrm{~g} / \mathrm{L} ; \mathbf{b}$ enzymatic saccatification of Avicel with mixture of AL $(2 \mathrm{~g} / \mathrm{L})$ and modified lignins $(2 \mathrm{~g} / \mathrm{L})$. Enzymatic saccharification was conducted at $50^{\circ} \mathrm{C}$ and $150 \mathrm{rpm}$ in the $0.05 \mathrm{M}$ sodium acetate buffer ( $\left.\mathrm{pH} 4.8\right)$ for $72 \mathrm{~h}$, with the cellulase (UTA-8) loading of $10 \mathrm{FPU} / \mathrm{g}$ glucan 
OL, and CL were $48.5,51.3$, and $49.4 \%$, respectively. The addition of SL, OL and CL enhanced the $72 \mathrm{~h}$ hydrolysis yield of Avicel by $8-15.3 \%$ than that of Avicel with AL. Remarkably, it was observed that OL from oxidized modification showed much higher stimulation than other two modified lignins. In addition, the enzymatic hydrolysis of Avicel with mixture of AL (2 g/L) and modified lignins $(2 \mathrm{~g} / \mathrm{L})$ are also assessed in Fig. 5b. As expected, the mixture with $\mathrm{AL}$ and modified lignins also weakened the inhibitory effect of AL alone on enzymatic hydrolysis under the same content of lignin. Particularly, addition of AL and CL had the highest glucose yield (53.6\%), followed by the mixture of AL and CL (51.36\%) and that of AL and SL (49.5\%), increased by $11.2-20.4 \%$ than AL of $4 \mathrm{~g} / \mathrm{L}$ alone (44.5\%).

Besides, the effect of modified lignins on the cellulase activity was assessed by measuring the free enzyme activity and the protein concentration of supernatant in the $72 \mathrm{~h}$ of hydrolysis process. As shown in Fig. 6, after $72 \mathrm{~h}$ incubation at $\mathrm{pH} 4.8$ and $50^{\circ} \mathrm{C}$, filter paper enzyme activity and protein content at the $72 \mathrm{~h}$ hydrolysis of Avicel alone retained 72.2 and $17.1 \%$ of its initial activity, while that of Avicel with $4 \mathrm{~g} / \mathrm{L}$ of AL decreased to 52.8 and 5.6\% of its starting activity, indicating that $27 \%$ cellulase activities and $67 \%$ protein were adsorbed to AL or inactivated by the nonproductive adsorption of cellulase onto lignins. However, the inhibitory effect of lignin on enzyme activity and protein content was greatly reduced, when $\mathrm{AL}$ were replaced with modified lignins. This improvement made enzyme activity percentage increased up to $59-61 \%$, and protein content percentage up to $14-15 \%$, which was $12-16 \%$ and $1.5-1.7$ times higher than cellulase activity and protein content of AL alone in the $72 \mathrm{~h}$ of hydrolysis process, respectively. The results suggested that the modified lignins did not lead to the decrease of

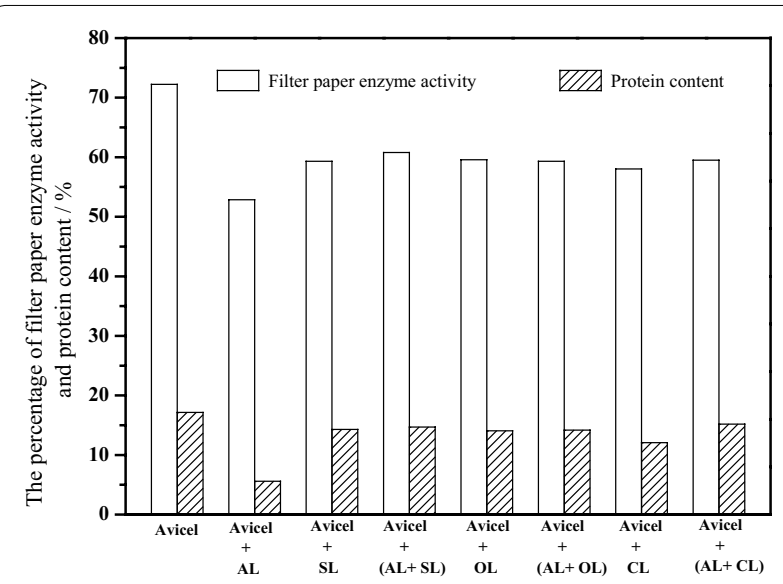

Fig. 6 Effect of modified lignins on relative enzyme activity and protein content at $72 \mathrm{~h}$ in enzymatic saccharification of cellulose cellulase activity in supernatant, on the contrary, can increase free cellulase enzymes and decrease cellulase activity loss than the presence of $\mathrm{AL}$, which can reduce the negative effect of lignin preparations on enzymatic digestibility.

\section{Effects of alkali pretreatment and post-treatment on glucose and xylose release in enzymatic hydrolysis of bamboo}

To verify whether lignin modifications as post-treatment technologies can work on lignocellulosic biomass, bamboo (P. amarus) was extracted with $10 \%(\mathrm{w} / \mathrm{w})$ sodium hydroxide at $70{ }^{\circ} \mathrm{C}$ for $3 \mathrm{~h}$, followed by sulfonation, oxidation and carboxylation post-treatment. As seen in Fig. 7, for each post-pretreatment, the increase of glucose and xylose release was observed in the hydrolysis process. Untreated $P$. amarus almost was not degraded by enzymatic cellulase due to the strong recalcitrance. The 5 days hydrolysis of alkali pretreated $P$. amarus (A-P. amarus) only obtained the glucose yield of $11.1 \%$. However, when alkali pretreatment was followed by the sulfonation, oxidation and carboxylation post-pretreatment, glucose yield was increased to $38.5 \%$ (AS-P. amarus), $15.4 \%$ (AO$P$. amarus), and $21.4 \%$ (AC-P. amarus), respectively. The corresponding xylose yield was also increased from 26.2 to $53.9,29$ and $30.9 \%$, respectively. And the enhancing effects caused by sulfonation post-treatment were greater than oxidation and carboxylation post-pretreatment. The results suggested that the post-pretreatment by modifying lignin can enhance glucose and xylose release in the enzymatic hydrolysis of lignocellulosic biomass. We believe that the increase of glucose and xylose yield after post-treatment can most likely be attributed to the decrease of lignin inhibition on enzymatic hydrolysis. In addition, it is important that alkali pretreatment is still considered as the appropriate method for developing the combined pretreatment technologies for reducing lignin inhibition on enzymatic hydrolysis. Because alkali pretreatment can decrease the lignin content, the sulfonation, oxidation, and carboxylation post-treatment can reduce the nonproductive adsorption of cellulase on lignin, which could contribute to the decrease of lignin inhibition together.

It was well known that lignocellulosic substrates pretreated with thermochemical methods have been reported to require subsequent post-treatment to enhance enzymatic saccharification efficiency by decreasing the lignin content and modifying the lignin structure [35]. Many studies on post-treatment had focused on a drop in the lignin content of pretreated substrates with the objective of delignification. The delignification is costly for the existing thermochemical pretreatment 

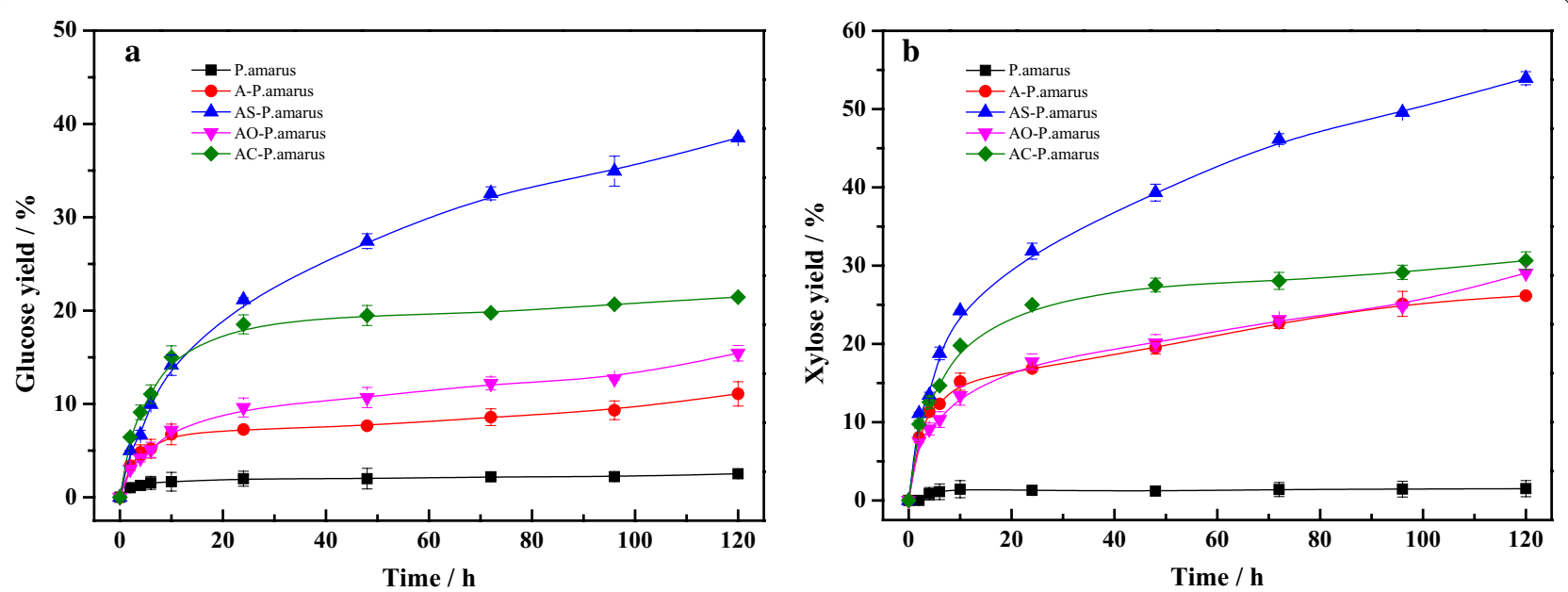

Fig. 7 The enzymatic hydrolysis efficiency of the combination with alkali pretreatment and sulfonation, oxidation, and carboxylation post-treatment in P. amarus. a Glucose yield. b Xylose yield

technologies and could bring about polysaccharides loss, which may be worth exploring at a later date. We believed that post-treatment with the objective of modifying the lignin structure, especially under the mild conditions, would attract considerable attention, which could help to design a pretreatment scheme for reducing the negative effect of lignin on enzymatic hydrolysis.

\section{Conclusions}

When the carboxylic, sulfonic acid, and oxidative groups were incorporated into $\mathrm{AL}$, the decrease of hydrophobic and hydrogen-bonding interactions and the increase of electrostatic interactions between modified lignins and enzyme cellulase were observed. Langmuir adsorption isotherms also proved that modified lignin had a lower binding ability to the cellulase enzyme than AL. Therefore, the $72 \mathrm{~h}$ glucose yields of Avicel with modified lignins increased from $44.5 \%$ for AL to $48.5 \%$ for SL, $49.4 \%$ for $\mathrm{CL}$, and $51.3 \%$ for OL, suggesting the drop of lignin inhibition on enzymatic digestion. Modified lignins made enzyme activity percentage increased by $12-16 \%$ at the $72 \mathrm{~h}$ of hydrolysis process than AL. In addition, we detected that combination of alkali pretreatment and sulfonation, oxidation and carboxylation post-treatment enhanced glucose yield of $P$. amarus by $28-71.2 \%$ and xylose yield by $15.2-51.4 \%$. This study is helpful to design a pretreatment scheme involving the sequential coupling of pretreatment methods and post-treatment with the objective of reducing the lignin inhibition on enzymatic hydrolysis.

\section{Methods}

\section{Chemicals and materials}

Alkali Lignin, a mixture of different herbaceous plants, such as corn stover, bamboo and straw, were supplied by Shanghai Yuanye Bio-Technology Co., Ltd (Shanghai), which was obtained by $\mathrm{NaOH}$ pretreatment and then purified by an acidulation precipitation method. The chemical composition of AL was as follows (dry weight basis): $90.9 \%$ acid insoluble lignin, 3.67\% acid soluble lignin, $0.1 \%$ glucan, $0.05 \%$ xylan, $2.19 \%$ ash, and $2.79 \%$ others. Microcrystalline cellulose (Avicel $\mathrm{PH}-101, \sim 50 \mu \mathrm{m}$ particle size) was purchased from Sigma-Aldrich (Shanghai). The bamboo (Pleioblastus amarus, $P$. amarus) was obtained from Yunnan, China and its glucan, xylan, and lignin contents were 41.7, 15.7 and $37.5 \%$, respectively. Cellulase (UTA-8) from Trichoderma reesei with the filter paper activity of $100 \mathrm{FPU} / \mathrm{mL}$ and the $\beta$-glucosidase activity of $71 \mathrm{IU} /$ $\mathrm{mL}$, was kindly donated by Youteer Biochemical Co., Ltd. (Hunan) and used in subsequent enzymatic saccharification of cellulose. Celluclast 1.5 L (Sigma 2730) from Sigma-Aldrich (Shanghai) exhibited the protein content of $40 \mathrm{mg} / \mathrm{mL}$ and was employed in experiments of cellulase adsorption.

\section{Lignin modification}

Three modified lignins were prepared from AL. Sulfonated Lignin (SL) was obtained by treating $10.0 \mathrm{~g} \mathrm{AL}$ with $30 \mathrm{~mL} \mathrm{NaOH}$ solution $(0.8 \mathrm{M})$ and $1.5 \mathrm{~mL}$ formaldehyde in $70{ }^{\circ} \mathrm{C}$ for $90 \mathrm{~min}$. Sodium sulfite of $2 \mathrm{~g}$ was mixed with the above solution to carry out sulfonation 
reaction at $95{ }^{\circ} \mathrm{C}$ and $3 \mathrm{~h}$ [36]. Oxidized Lignin (OL) was prepared based on the Fenton oxidation reaction reported in previous literature $[37,38]$. In brief, AL $(5 \mathrm{~g})$ was dissolved in $100 \mathrm{~mL}$ deionized water with a little $\mathrm{NaOH}$ at $50{ }^{\circ} \mathrm{C}$ and the $\mathrm{pH}$ was adjusted to $3-5$. The $30 \% \mathrm{H}_{2} \mathrm{O}_{2}$ of $2 \mathrm{~mL} / \mathrm{g}$ lignin and $\mathrm{FeSO}_{4}(16 \mathrm{mM})$ were added in the solution and the mixture was reacted at room temperature $\left(22 \pm 1{ }^{\circ} \mathrm{C}\right)$ and $80 \mathrm{rpm}$ in a water bath for $24 \mathrm{~h}$. Carboxylated Lignin (CL) was prepared through the reaction between hydroxyl groups and sodium chloroacetate, as described previously [39]. The solution of AL was mixed with sodium chloroacetate of $4 \mathrm{~mol} / \mathrm{L}$ at the ratio of $2: 1$. The reaction was conducted at $70{ }^{\circ} \mathrm{C}$ for $90 \mathrm{~min}$. After the reaction, the $\mathrm{pH}$ of solution was adjusted to precipitate lignin, and the sample was collected by centrifugation, washed with warm water and dried under vacuum.

\section{Surface and structural analysis of lignin preparations}

The lignin preparations were analyzed using a 710 FTIR spectrophotometer (Nicolet, USA). The ${ }^{13} \mathrm{C}$ and HSQC NMR spectra of lignins were acquired with a Bruker AVIII $400 \mathrm{MHz}$ spectrometer. The sample $(80 \mathrm{mg}$ ) was placed in NMR tubes with $0.5 \mathrm{~mL}$ dimethyl sulfoxided6. 2D HSQC spectra were recorded on the same spectrometer using 128 scanning time, a 2.6-s delay time between transients, and a 1.5-s relaxation time. X-ray photoelectron spectroscopy (XPS) analyses was conducted on an Escalab 250Xi spectrometer (Thermo Fisher Scientific Inc., US), with non-monochromatic $\mathrm{Al} K$ alph (X-ray-voltage $15 \mathrm{kV}, 300 \mathrm{~W}, \mathrm{X}$-ray energy $1486.8 \mathrm{eV}$ ), under a high vacuum of $2 \times 10^{-9} \mathrm{mbar}$ and at room temperature. The content of free phenolic group in lignin samples were estimated by the FolinCiocalteu $(\mathrm{F}-\mathrm{C})$ method using phenol as standard [24, $40,41]$. The contact angle was measured using OCA20 contact angle meter (Dataphyscis Inc., Germany) at room temperature $\left(22 \pm 1{ }^{\circ} \mathrm{C}\right)$. The average contact angle $(\theta)$ values were obtained from measurements at three points in each lignin surface. The measurements of Zeta potentials were analyzed using a Malvern Zetasizer Nano ZS instrument. Lignin preparations $(0.01 \%$, $\mathrm{w} / \mathrm{w})$ were incubated in $0.05 \mathrm{M}$ citrate buffer $(\mathrm{pH} 4.8)$ for $1 \mathrm{~h}$, followed by determination of zeta potential. The reported result of each sample was the average of three trials.

\section{Enzyme adsorption isotherm of lignin preparations}

The adsorption isotherm of enzyme on lignin preparations was studied with different concentration cellulases from 0.01 to $2 \mathrm{mg} / \mathrm{mL}$ [42]. Lignins and enzymes were incubated in $0.05 \mathrm{M}$ citrate buffer at $4{ }^{\circ} \mathrm{C}$ under shaking
(150 rpm) for $3 \mathrm{~h}$ to reach equilibrium. The concentration of free proteins in the solution was monitored using Bradford method. The adsorbed enzyme was calculated by subtracting the amount of free proteins from the total initial protein amount. All adsorption reactions were run in parallel. Maximum adsorption capacity $\left(\Gamma_{\mathrm{m}}, \mathrm{mg} / \mathrm{g}\right.$ lignin) and affinity constant were estimated by nonlinear regression of adsorption data according to the Langmuir isotherm equation $\left(\Gamma=\Gamma_{\mathrm{m}} K C /(1+K C)\right)$, where $\Gamma$ is the amount of adsorbed enzyme ( $\mathrm{mg} / \mathrm{g}$ substrate), $C$ the amount of free enzyme in solution $(\mathrm{mg} / \mathrm{mL})$ and $K$ the Langmuir constant ( $\mathrm{mL} / \mathrm{mg}$ enzyme). And the distribution coefficient $\left(R=\Gamma_{\mathrm{m}} \times K \mathrm{~L} / \mathrm{g}\right)$, represented binding strength, was also analyzed.

\section{Enzymatic hydrolysis \\ Enzymatic hydrolysis of Avicel}

Enzymatic hydrolysis was conducted at $50{ }^{\circ} \mathrm{C}$ and $150 \mathrm{rpm}$ in the $0.05 \mathrm{M}$ sodium acetate buffer $(\mathrm{pH} 4.8)$ for $72 \mathrm{~h}$, with a solid substrate loading of $2 \%(\mathrm{w} / \mathrm{v})$ Avicel. The dosage of cellulase (UTA-8) was $10 \mathrm{FPU} / \mathrm{g}$ glucan. To investigate the effects of lignin compounds (AL, SL, OL, and $\mathrm{CL}$ ) on enzymatic hydrolysis, the $4 \mathrm{~g} / \mathrm{L}$ lignin sample (AL, SL, OL, and CL, respectively) or the mixture of $2 \mathrm{~g} / \mathrm{L}$ AL with $2 \mathrm{~g} / \mathrm{L}$ (SL, OL, and CL) were added into pure cellulose, respectively, prior to the addition of cellulase. Enzymatic saccharification with addition of $\mathrm{AL}$ only was used as the control. Aliquots $(0.2 \mathrm{~mL})$ were withdrawn from the supernatant at 2, 4, 6, 10, 24, 48 and $72 \mathrm{~h}$ of hydrolysis. Quantitative analyses of glucose were measured by an Agilent 1260 series HPLC equipped with Aminex HPX-87H column at $60{ }^{\circ} \mathrm{C}$ column temperature, using $5 \mathrm{mM} \mathrm{H}_{2} \mathrm{SO}_{4}$ as eluent at the flow rate

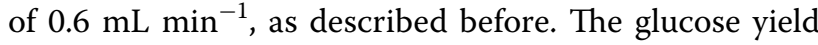
was defined as the percentage of the glucose content in hydrolysate based on the theoretical glucose available in the cellulose. And protein concentration in supernatant was determined by Bradford assay, and calculated based on the total protein concentration. The relative enzyme activity at $72 \mathrm{~h}$ of enzymatic hydrolysis was also measured using the filter paper assay [43].

\section{Enzymatic hydrolysis of lignocellulosic biomass}

P. amarus was extracted at $70{ }^{\circ} \mathrm{C}$ for $3 \mathrm{~h}$ with $10 \% \mathrm{NaOH}$ (w/w) based on the dry weight of biomass, in a solid to liquid ratio of 1:10 (w/w). After washing with water, the solid residue was subjected to sulfonation, oxidation and carboxylation post-treatment; the post-treatment condition was the same as that of the AL. The effects of combination of alkali pretreatment and post-treatment were evaluated based on the subsequent glucose and xylose release in the hydrolysate. Enzymatic hydrolysis of pretreated substrates was conducted at $50{ }^{\circ} \mathrm{C}, \mathrm{pH} 4.8$ and 
$150 \mathrm{rpm}$ for 5 days, with a substrate loading of $5 \%(\mathrm{w} / \mathrm{v})$ and a cellulase (UTA-8) loading of 20 FPU/g glucan. The glucose and xylose yield were defined as weight percent yield of glucose and xylose with respect to the total glucan and xylan in the bamboo biomass. The compositions of alkali pretreated P. amarus (A-P. amarus) were $51.8 \%$ glucan, $17.5 \%$ xylan, and $35.1 \%$ lignin. The combination with alkali pretreatment and sulfonation, oxidation and carboxylation post-treatment of $P$. amarus was defined as AS-P. amarus and AO-P. amarus and AC-P. amarus, respectively. After post-treatment, AS-P. amarus contained $50.9 \%$ glucan, $13.1 \%$ xylan, and $23.4 \%$ lignin; and AO-P. amarus $54.4 \%$ glucan, $15 \%$ xylan, and $27.1 \%$ lignin; and AC-P. amarus $60.9 \%$ glucan, $14.8 \%$ xylan, and $21.6 \%$ lignin, respectively.

\section{Abbreviations}

SL: Sulfonated Lignin; OL: Oxidized Lignin; CL: Carboxylated Lignin; AL: Alkali Lignin; A-P. amarus: P. amarus pretreated with alkali; AS-P. amarus: P. amarus pretreated with alkali and sulfonation post-pretreatment; AO-P. amarus: $P$. amarus pretreated with alkali and oxidation post-pretreatment; AC-P. amarus: P. amarus pretreated with alkali and carboxylation post-pretreatment; S-lignin: syringyl lignin; H-lignin: $p$-hydroxyphenyl lignin; G-lignin: guaiacyl lignin; FA: ferulic acid; pCA: $p$-coumarates; XPS: X-ray photoelectron spectroscopy; HPLC: High-performance liquid chromatography; FTIR: Fourier transform infrared spectroscopy; $13 \mathrm{C}$ NMR: ${ }^{13} \mathrm{C}$ nuclear magnetic resonance; HSQC spectra: Heteronuclear single-quantum coherence spectra; $\mathrm{F}-\mathrm{C}$ method: Folin-Ciocalteu method.

\section{Authors' contributions}

WY completed performed the major experiments, analyzed the data, and prepared the manuscript. ZS, HY, GX, ZZ, and JY helped with the lignin modification experiments and the instrumental analysis. All authors read and approved the final manuscript.

\section{Author details}

${ }^{1}$ Key Laboratory for Forest Resources Conservation and Utilization in the Southwest Mountains of China, Ministry of Education, Southwest Forestry University, Kunming 650224, China. ${ }^{2}$ School of Chemical Engineering, Southwest Forestry University, Kunming 650224, China.

\section{Acknowledgements}

The authors are grateful for the support of this study by the National Natural Science Foundation of China (No. 31760194), Yunnan Province Agricultural Basic Research Joint Program [No. 2017FG001(-025)], Yunnan Provincial Department of Education Science Research Fund Project (No. 2017YJS092), and the Open Fund of Guangxi Key laboratory of Chemistry and Engineering of Forest Products (GXFC-08).

\section{Competing interests}

The authors declare that they have no competing interests.

\section{Availability of data and materials}

All data generated or analyzed during this study are included in this published article.

\section{Consent for publication}

All the authors consented on the publication of this work.

\section{Ethics approval and consent to participate}

Not applicable.

\section{Funding}

Funding sources have been addressed in the Acknowledgements.

\section{Publisher's Note}

Springer Nature remains neutral with regard to jurisdictional claims in published maps and institutional affiliations.

Received: 2 May 2018 Accepted: 25 July 2018

Published online: 01 August 2018

\section{References}

1. Sheldon RA. Green and sustainable manufacture of chemicals from biomass: state of the art. Green Chem. 2014;16(3):950-63.

2. Dale BE, Anderson JE, Brown RC, Csonka S, Dale VH, Herwick G, Jackson RD, Jordan N, Kaffka S, Kline KL, Lynd LR, Malmstrom C, Ong RG, Richard TL, Taylor C, Wang MQ. Take a closer look: biofuels can support environmental, economic and social goals. Environ Sci Technol. 2014;48:7200-3.

3. Moraïs S, Morag E, Barak Y, Goldman D, Hadar Y, Lamed R, Shoham Y, Wilson DB, Bayer EA. Deconstruction of lignocellulose into soluble sugars by native and designer cellulosomes. mBio. 2012;3(6):214104-12.

4. Gregg DJ, Saddler JN. Factors affecting cellulose hydrolysis and the potential of enzyme recycle to enhance the efficiency of an integrated wood to ethanol process. Biotechnol Bioeng. 1996;51(4):375-83.

5. Mccarthy JL, Islam A. Lignin chemistry, technology, and utilization: a brief history. ACS Symp Ser. 2000;742:2-99.

6. Fang Z, Smith RL Jr. Production of biofuels and chemicals from lignin., Biofuels and BiorefineriesHeidelberg: Springer; 2016.

7. Voxeur A, Wang Y, Sibout R. Lignification: different mechanisms for a versatile polymer. Curr Opin Plant Biol. 2015;23:83-90.

8. Mooney CA, Mansfield SD, Touhy MG, Saddler JN. The effect of initial pore volume and lignin content on the enzymatic hydrolysis of softwoods. Bioresour Technol. 1998;64:113-9.

9. Kumar L, Arantes V, Chandra R, Saddler J. The lignin present in steam pretreated softwood binds enzymes and limits cellulose accessibility. Bioresour Technol. 2012;103:201-8.

10. Sipos B, Dienes D, Schleicher A, Perazzini R, Crestini C, Siika-aho M, Reczey K. Hydrolysis efficiency and enzyme adsorption on steam-pretreated spruce in the presence of poly (ethylene glycol). Enzyme Microb Technol. 2010;47:84-90

11. Zheng Y, Pan Z, Zhang R, Wang D, Jenkins B. Non-ionic surfactants and non-catalytic protein treatment on enzymatic hydrolysis of pretreated creeping wild ryegrass. Appl Biochem Biotechnol. 2008;146:231-48.

12. Wang ZJ, Zhu JY, Fu YJ, Qin MH, Shao ZY, Jiang JG, Yang F. Lignosulfonatemediated cellulase adsorption: enhanced enzymatic saccharification of lignocellulose through weakening nonproductive binding to lignin. Biotechnol Biofuels. 2013;6:156.

13. Liu H, Zhu J, Fu S. Effects of lignin-metal complexation on enzymatic hydrolysis of cellulose. J Agric Food Chem. 2010;58:7233-8.

14. Akimkulova A, Zhou Y, Zhao XB, Liu DH. Improving the enzymatic hydrolysis of dilute acid pretreated wheat straw by metal ion blocking of non-productive cellulase adsorption on lignin. Bioresour Technol. 2016;208:110-6.

15. Pan X. Role of functional groups in lignin inhibition of enzymatic hydrolysis of cellulose to glucose. J Biobased Mater Bioenergy. 2008;2:25-32.

16. Sewalt V, Glasser W, Beauchemin K. Lignin impact on fiberdegradation. 3. Reversal of inhibition of enzymatic hydrolysis by chemical modification of lignin and by additives. J Agric Food Chem. 1997:45:1823-8.

17. Nakagame S, Chandra RP, Kadla JF, Saddler JN. Enhancing the enzymatic hydrolysis of lignocellulosic biomass by increasing the carboxylic acid content of the associated lignin. Biotechnol Bioeng. 2011;108:538-48.

18. Papa G, Varanasi P, Sun L, Cheng G, Stavila V, Holmes B, Simmons BA, Adani F, Singh S. Exploring the effect of different plant lignin content and composition on ionic liquid pretreatment efficiency and enzymatic saccharification of Eucalyptus globulus L. mutants. Bioresour Technol. 2012;117:352-9.

19. Davison BH, Drescher SR, Tuskan GA, Davis MF, Nghiem NP. Variation of $S / G$ ratio and lignin content in a Populus family influences the release of xylose by dilute acid hydrolysis. Appl Biochem Biotechnol. 2006;130:427-35.

20. Bonawitz ND, Soltau WL, Blatchley MR, Powers BL, Hurlock AK, Seals LA, Weng JK, Stout J, Chapple C. REF4 and RFR1, subunits of the 
transcriptional coregulatory complex mediator, are required for phenylpropanoid homeostasis in Arabidopsis. J Biol Chem. 2012;287:5434-45.

21. Jung JH, Vermerris W, Gallo M, Fedenko JR, Erickson JE, Altpeter F. RNA interference suppression of lignin biosynthesis increases fermentable sugar yields for biofuel production from field-grown sugarcane. Plant Biotechnol J. 2013;11:709-16.

22. Bonawitz ND, Im Kim J, Tobimatsu Y, Ciesielski PN, Anderson NA, Ximenes E, Maeda J, Ralph J, Donohoe BS, Ladisch M. Disruption of mediator rescues the stunted growth of a lignin-deficient arabidopsis mutant. Nature. 2014:509:376-80

23. Faix O. Classification of lignins from different botanical origins by FT-IR spectroscopy. Holzforschung. 1991;45:21-8.

24. Wen JL, Sun SL, Yuan TQ, Xu F, Sun RC. Structural Elucidation of lignin polymers of Eucalyptus Chips during organosolv pretreatment and extended delignification. J Agric Food Chem. 2013;61:11067-75.

25. Capanema EA, Balakshin MY, Kadla JF. A comprehensive approach for quantitative lignin characterization by NMR spectroscopy. J Agric Food Chem. 2004;52:1850-60.

26. Sun SL, Huang Y, Sun RC, Tu MB. The strong association of condensed phenolic moieties in isolated lignins with their inhibition of enzymatic hydrolysis. Green Chem. 2016;18:4276-86.

27. Wen JL, Xue BL, Xu F, Sun RC, Pinkert A. Unmasking the structural features and property of lignin from bamboo. Ind Crops Prod. 2013;42:332-43.

28. Lu F, Ralph J. Detection and determination of $p$-coumaroylated units in lignins. J Agric Food Chem. 1999;47:1988-92.

29. Grabber JH, Hatfield RD, Ralph J, Zon J, Amrhein N. Ferulate cross-linking in cell-walls isolated from maize cell-suspensions. Phytochemistry. 1995;40:1077-82.

30. Jacquet G, Pollet B, Lapierre C, Mhamdi F, Rolando C. New ether-linked ferulic acid-coniferyl alcohol dimers identified in grass straws. J Agric Food Chem. 1995:43:2746-51.

31. Bunzel M, Ralph J, Lu F, Hatfield RD, Steinhart H. Lignins and ferulateconiferyl alcohol cross-coupling products in cerealgrains. J Agric Food Chem. 2004;52:6496-502.

32. Fiddler W, Parker WE, Wasserman AE, Doerr RC. Thermal decomposition of ferulic acid. J Agric Food Chem. 1967;15(5):757.
33. Wysokowski M, Klapiszewski Ł, Moszyński D, Bartczak P, Szatkowski T, Majchrzak I, Siwińska-Stefańska K, Bazhenov VV, Jesionowski T. Modification of chitin with kraft lignin and development of new biosorbents for removal of cadmium(II) and nickel(II) ions. Mar Drugs. 2014;12(4):2245-68.

34. Lange H, Schiffels P, Sette M, Sevastyanova O, Crestini C. Fractional precipitation of wheat straw organosolv lignin: macroscopic properties and structural insights. ACS Sustain Chem Eng. 2016;4(10):5136-51.

35. Fang Z. Pretreatment techniques for biofuels and biorefineries., Green energy \& technologyHeidelberg: Springer; 2013.

36. Zhou H, Lou H, Yang D, Zhu J, Qiu X. Lignosulfonate to enhance enzymatic saccharification of lignocelluloses: role of molecular weight and substrate lignin. Ind Eng Chem Res. 2013;52(25):8464-70.

37. Wu K, Ying WJ, Shi ZJ, Yang HY, Zheng ZF, Zhang JY, Yang J. Enhancing effect of residual lignins from $D$. sinicus pretreated with fenton chemistry on enzymatic digestibility of cellulose. Energy Technol. 2018. https://doi. org/10.1002/ente.201700880

38. Wu K, Ying WJ, Shi ZJ, Yang HY, Zheng ZF, Zhang JY, Yang J. Fenton reaction-oxidized bamboo lignin surface and structural modification to reduce nonproductive cellulase binding and improve enzyme digestion of cellulose. ACS Sustain Chem Eng. 2018;6(3):3853-61.

39. An NT, Dong NT, Dung PL, Thien DT. Synthesis and characterization of water-soluble O-carboxymethyl glucomannan derivatives. Carbohydr Polym. 2011;83(2):645-52.

40. Wu K, Shi ZJ, Yang HY, Liao ZD, Yang J. Effect of ethanol organosolv lignin from bamboo on enzymatic hydrolysis of Avicel. ACS Sustain Chem Eng. 2017;5(2):1721-9.

41. Ainsworth EA, Gillespie KM. Estimation of total phenolic content and other oxidation substrates in plant tissues using Folin-Ciocalteu reagent. Nat Protoc. 2007:2:875-7.

42. Lai CH, Tu MB, Xia CL, Shi ZQ, Sun SL, Yong Q, Yu SY. Lignin alkylation enhances enzymatic hydrolysis of lignocellulosic biomass. Energy Fuels. 2017;31:12317-26.

43. Ghose TK. Measurement of cellulase activities. Pure Appl Chem. 1987;59:257-68.
Ready to submit your research? Choose BMC and benefit from:

- fast, convenient online submission

- thorough peer review by experienced researchers in your field

- rapid publication on acceptance

- support for research data, including large and complex data types

- gold Open Access which fosters wider collaboration and increased citations

- maximum visibility for your research: over 100M website views per year

At $\mathrm{BMC}$, research is always in progress.

Learn more biomedcentral.com/submissions 